(Житомирський державний університет імені Івана Франка)

\title{
ЦИКЛОВА МЕТОДИЧНА КОМІСІЯ ЯК СЕРЕДОВИЩЕ РОЗВИТКУ ПЕДАГОГІЧНОӤ КОМПЕТЕНТНОСТІ ВИКЛАДАЧІВ ФАРМАЦЕВТИЧНОГО ПРОФІЛЮ
}

У статті розглядається роль цииклової методичної комісії фармацевтичних дисциплін у розвитку педагогічної компетентності викладачів фармацевтичного профілю; визначено зміст роботи ичиклової методичної комісії, структуру педагогічної компетентності; з'ясовано роль викладача фармацевтичного профілю в освітньому процесі закладу вищої освіти. Акцентовано, щуо саме цииллова комісія створює систему науково - методичної роботи, націлену на забезпечення розвивального ефекту освітнього процесу, сприяє розвитку у викладачів фармацевтичного профілю педагогічної компетентності.

Ключові слова: иүиклова методична комісія фармацевтичних дисциплін, викладачі фармацевтичного профілю, розвиток педагогічної компетентності.

Постановка проблеми. Проблема розвитку педагогічної компетентності викладачів закладів вищої освіти фармацевтичного профілю набуває актуальності в умовах реформування освітньої галузі, яка, інтегруючись в міжнародне співтовариство, ставить нові вимоги до викладача вищої школи, його особистості і професійної діяльності. Водночас існує проблема розвитку та формування педагогічної компетентності викладачів закладу вищої освіти фармацевтичного профілю, які орієнтуються на реалізацію сумісної діяльності фармацевтичної та освітньої галузей, а тому повинні інтегрувати в собі якості, характерні для успішного виконання і однієї, й іншої видів діяльності. Динамічність педагогічної компетентності викладача коледжу, що виявляється у їі розвитку, залежить від ефективності організації науково-методичної роботи коледжу, зокрема від злагодженої та змістовної роботи циклової методичної комісії фармацевтичних дисциплін.

Аналіз основних досліджень i публікацій із зазначеної проблеми. Професійну діяльність i професійне становлення викладача закладу вищої освіти вивчали С. Вітвицька, О. Гура, I. Ісаєв, Н. Кузьміна, В. Лозовецька, Л. Макарова, Ю. Поваренков, Ю. Фокін та ін.; організацію навчальновиховної та науково-методичної роботи у вищих медичних, фармацевтичних навчальних закладах III p.а. розглядали О. Гуменюк, С. Бухальська, Р. Сабадишин, Т. Чернишенко, М. Шегедин; достатня увага приділяється вивченню проблеми з організації методичної роботи у закладі освіти вченими: I. Жерносек, В. Пікельна; ролі методичної роботи у підвищенні професійно-педагогічної компетентності викладача С. Бухальська, О. Козаченко, В. Сгадова, Л. Сушенцева; функціонування методичного кабінету як центру науково - методичної роботи коледжу - Г. Данилова, Р. Сердюкова, Т. Чернишенко. До вивчення теорії та практики розвитку педагогічної компетентності викладачів закладів вищої освіти непедагогічного профілю долучаються С. Бухальська, О. Гура, С. Демченко, Т. Лебединець, І. Міщенко та ін.

У даній статті маємо на меті довести важливість циклової методичної комісії фармацевтичних дисциплін у розвитку педагогічної компетентності викладачів фармацевтичного профілю через різні форми і види діяльності.

Виклад основного матеріалу. Розвиток української фармацевтичної освіти грунтується на введенні якісно нової методології організації освітнього процесу за європейським зразком [1]. В основу концепції закладено європейські тенденції та національну стратегію. Важлива роль в організації освітнього процесу відводиться цикловим методичним комісіям, зокрема, із фармацевтичних дисциплін. Циклова методична комісія - структурний підрозділ закладу освіти I-II рівнів акредитації - об'єднання викладачів однієї або кількох споріднених дисциплін.

Основною формою діяльності циклової методичної комісії фармацевтичних дисциплін є засідання, які проводяться не рідше одного разу на місяць.

Згідно з Положенням про циклову методичну комісію Житомирського базового фармацевтичного коледжу зміст роботи циклових комісій визначається з урахуванням загальної методичної проблеми та конкретних завдань, що стоять перед закладом освіти, і здійснюється за такими напрямами:

- участь у розробці складових стандартів вищої освіти;

- координація розробки та забезпечення виконання навчальних планів і навчальних програм;

- розгляд, обговорення та затвердження плану роботи циклової методичної комісії, навчальних та робочих програм, індивідуальних робочих планів викладачів;

- розробка, удосконалення навчально-методичних комплексів забезпечення навчальних дисциплін;

- планування, обговорення та затвердження навчально-методичних розробок викладачів; 
- координація створення рукописів навчальної літератури (навчальних підручників, посібників, практикумів, робочих зошитів тощо), розгляд іï, обговорення, науково-методичний супровід рецензування;

- розробка та впровадження в освітній процес заходів, спрямованих на забезпечення якісної підготовки фахівців, чіткої організації навчального процесу;

- розробка, апробація і впровадження методик викладання навчальних дисциплін циклової методичної комісії, проведення лекційних, практичних, лабораторних, семінарських занять, різних видів практик;

- планування, методичний супровід та обговорення (аналіз) відкритих занять;

- вивчення, поширення кращого (передового) досвіду роботи викладачів, надання дієвої допомоги викладачам-початківцям в оволодінні педагогічною майстерністю;

- застосування сучасних інформаційних технологій, вивчення їх ефективності для навчального процесу та освітньої діяльності в цілому, впровадження їх в організаційну діяльність циклової методичної комісії;

- підготовка, розгляд, обговорення та затвердження матеріалів контролю результатів навчання студентів;

- аналіз якості знань студентів, контроль об'єктивності оцінювання результатів навчання студентів, вироблення єдиних норм та вимог до їх оцінки;

- організація проведення тижня циклової методичної комісії;

- організація та проведення заходів тематичного, професійного, науково-дослідницького, творчого характеру: науково-практичних конференцій, олімпіад, конкурсів, вікторин тощо;

- участь в організації підвищення кваліфікації викладачів циклової методичної комісії, проходження ними атестації;

- розвиток матеріально-технічної бази кабінетів і лабораторій.

На циклову методичну комісію фармацевтичних дисциплін, до складу якої входять викладачіфармацевти, у коледжі покладається особлива відповідальність, ії діяльність планується з урахуванням розвитку педагогічної компетентності викладачів фармацевтичного профілю, частина заходів даного напряму відображається у плані роботи циклової методичної комісії, а також в індивідуальному плані роботи викладача, оформленому відповідно до наказу МОН України "Про затвердження норм часу для планування і обліку навчальної роботи та перелік основних видів методичної, наукової й організаційної роботи педагогічних і науково-педагогічних працівників ВНЗ" від 07.08.2002 p. № 450. У зазначеному наказі до основних видів науково-методичної роботи віднесено:

- "підготовку конспектів лекцій; методичних матеріалів до семінарських, практичних, лабораторних занять, курсового проектування, практик і самостійної роботи студентів;

- підготовку, рецензування підручників, навчальних посібників;

- розробку навчальних планів; навчальних програм; робочих навчальних програм;

- підготовку комп’ютерного програмного забезпечення навчальних дисциплін;

- складання екзаменаційних білетів, завдань для проведення модульного, тестового, підсумкового контролю;

- розробку і впровадження наочних навчальних посібників;

- розробку і впровадження нових форм, методів і технологій навчання;

- вивчення і впровадження передового досвіду організації навчального процесу". Основні види наукової роботи такі: написання наукових статей; підготовка тез доповідей на конференціях, семінарах, керівництво науковою роботою студентів [3]. До основних видів організаційної роботи належать:

- робота у науково-методичних радах, об’єднаннях закладу освіти;

- організація й проведення загальноколеджних конференцій, семінарів;

- робота з видання науково-методичних збірників;

- керівництво студентським науковим гуртком, творчою групою викладачів та інші види робіт.

Аналіз напрямів і змісту науково-методичної роботи циклової методичної комісії фармацевтичних дисциплін дозволяє стверджувати, що вони забезпечують координацію освітнього процесу закладу вищої освіти, а також сприяють розвитку педагогічної компетентності викладачів фармацевтичного профілю. Під розвитком педагогічної компетентності викладачів фармацевтичного профілю розуміємо керований цілеспрямований, багатофакторний процес, який призводить до стійких якісних змін у діяльності викладача, виникнення нових змістових особистісних структур.

Розглянемо структуру педагогічної компетентності викладача фармацевтичного профілю, яка представлена у чотирьох компонентах: ціннісно-мотиваційному, діяльнісному, пізнавальному i особистісному, кожен з яких включає:

1) мотиви, орієнтовані на процес і результат педагогічної діяльності; мотиви, орієнтовані на реалізацію потреб самого викладача; 
2) знання: фахові, психологічні, педагогічні, методологічні, методичні, інформаційні, технологічні, мовно-мовленнєві, культурологічні та соціокультурні;

3) уміння: прогнозу вальні, проектувальні, конструювальні, комунікативні, інформаційнотехнологічні, організаторські, рефлексивні, ціннісно-орієнтаційні;

4) здібності: дидактичні, академічні, мовні, комунікативні, перцентивні, організаторські, лідерські. Особистісні якості: загальнолюдські, особистісно-етичні, індивідуально-психологічні, педагогічні.

Забезпечити розвиток усіх компонентів педагогічної компетентності можливо за умови активної участі викладачів фармацевтичного профілю в різних індивідуальних та колективних формах науковометодичної роботи циклової методичної комісії. Найбільш ефективними у вирішенні даного завдання $\epsilon$ наступні форми роботи:

- засідання, на яких викладач є доповідачем з актуальних освітніх питань;

- відкриті заняття, їх проведення, а також відвідування, аналіз й обговорення;

- науково-практичні конференції, їх організація або участь - у підготовці виступу на конференції, викладач має інформувати зібрання про свої педагогічні досягнення, обмінятись педагогічними знахідками, а це стає можливим лише за умови попередньої наукової роботи;

- методична доповідь - це публічне повідомлення на навчальну, методичну, виховну теми. У доповіді узагальнюється кращий педагогічний досвід роботи викладача чи викладачів, у ній слід вказувати недоліки та шляхи їх подолання. Тема доповіді повинна бути актуальною, і розкриватись глибоко й повно незважаючи на стислість викладу;

- написання наукових статей, рецензій, підготовка до видання навчальної літератури - ці види роботи розвивають різні види знань, умінь, зокрема методологічні та методичні;

- педагогічні читання, у процесі яких виявляється кращий педагогічний досвід у межах закладу освіти, розкривається роль наукового пошуку в освітньому процесі;

- педагогічні фестивалі, аукціони, референдуми, диспути, телемости, які сприяють розвитку творчого стилю педагога;

тиждень фармацевтичної науки, така форма роботи сприяє систематизації найновіших фахових знань та розробки інноваційних педагогічних технологій з їх впровадження;

- дискусійний клуб циклової комісії - це форма вільного спілкування ії членів. Учасники клубу особи, зацікавлені обговорюваною проблемою. На засіданні клубу відбувається вільний обмін думками, досвідом роботи. Тут немає заздалегідь підготовлених доповідачів, рішень. Тому на засіданні відбувається звичайний взаємообмін поглядами, взаємозбагачення ідеями;

педагогічні дослідження циклова комісія організовує для вивчення ефективності роботи викладачів, встановлення рівня оптимальності нових форм і методів навчально-виховного процесу та доцільності їх впровадження, визначення причин, які породжують недоліки в процесі навчання та виховання.

Діяльність викладача включає в себе виконання цілісної сукупності взаємопов'язаних і взаємообумовлених функцій, основними 3 яких $\epsilon$ навчальна, науково-методична, виховна i організаційно-технологогічна функції. Вони повинні сприйматися в їх єдності, хоча насправді у багатьох викладачів одні функції можуть переважати над іншими. У процесі реалізації функцій педагогічної діяльності викладач повинен виконувати такі групи завдань: проектування навчального процесу 3 урахуванням поставлених цілей; конструювання змісту та процесу навчання; організація аудиторних занять та самостійної роботи студентів; здійснення управління освітнім процесом. У межах виховної функції викладач формує у студентів творчо-активну установку на майбутню професію, їх світоглядну і громадянську позицію, загальну культуру, широту кругозору та етику поведінки; почуття власної відповідальності за результати своєї праці тощо. У галузі наукових досліджень викладач повинен формулювати наукову проблему, висувати наукову гіпотезу, використовувати методи наукових досліджень, формулювати та обгрунтовувати результати наукових досліджень, оформлювати їх у вигляді статей, доповідей тощо. Головне, бути вмотивованим на діяльність викладача та постійно саморозвиватися, що $є$ можливим за умови розвитку педагогічної компетентності.

Висновки. Розвиток педагогічної компетентності викладача фармацевтичного профілю коледжу найбільш активно здійснюється у системі науково-методичної роботи, основною ланкою якої є циклові методичні комісії. Аналіз напрямів і змісту роботи циклової методичної комісії фармацевтичних дисциплін засвідчив, що для ії ефективності важливими принципами мають бути: добір раціональних форм; свобода педагогічної творчості викладачів, їх право на інноваційну діяльність; забезпечення прав педагогічних працівників на вільний вибір форм, методів, засобів навчання, визначення результативності їх педагогічної діяльності винятково за рівнем якості знань студентів; уникнення формальної звітної та іншої документації.

На основі аналізу діяльності викладача фармацевтичного профілю у форматі циклової методичної комісії було з'ясовано, що педагогічна компетентність викладача коледжу виявляється в здатності здійснювати конкретні види роботи: розробка науково-методичного супроводу навчально-методичного 
забезпечення дисципліни; створення, розробка та упровадження в освітній процес науково-методичних напрацювань; проведення відкритих занять та їх самоаналіз, а також рефлексію щодо аналізу колег у процесі обговорення; підготовку навчально-методичної літератури до видання; апробація та впровадження в освітній процес інноваційних педагогічних технологій; підготовку та процес проходження підвищення кваліфікації; участь у презентаційних фахово-педагогічних заходах: конференціях, виставках, семінарах тощо; активність у процесах реформування професійної освіти, зокрема в обговоренні змін системи стандартів та нормативної бази.

Формами організації науково-методичної роботи, що сприяють розвитку педагогічної компетентності викладача, визначено методичний супровід його педагогічного зростання й поширення власного досвіду серед педагогічної спільноти.

\section{СПИСОК ВИКОРИСТАНИХ ДЖЕРЕЛ І ЛІТЕРАТУРИ}

1. Міщенко С. Г. Науково-методична робота як підгрунтя розвитку професійної компетентності викладача коледжу / С. Г. Міщенко // Педагогіка формування творчої особистості у вищій і загальноосвітній школах : [зб. наук. пр.] / [Редкол. : Т. І. Сущенко (голов. ред.) та ін.]. - Запоріжжя : КПУ, 2016. - Вип. 51 (104). C. $239-245$.

2. Фарафонова А. К. Циклова комісія, як важлива ланка системи управління навчально-методичною роботою / А. К. Фарафонова // Сучасні проблеми і шляхи вдосконалення управління вищими навчальними закладами III рівнів акредитації : [збірник матеріалів науково-практичної конференції педагогічних працівників вищих навчальних закладів I-II рівнів акредитації Харківської області (24 лютого 2006 р.)]. - Харків, 2013. - С. 225226.

3. Про затвердження норм часу для планування і обліку навчальної роботи та переліків основних видів методичної, наукової й організаційної роботи педагогічних і науково-педагогічних працівників вищих навчальних закладів: наказ МОН України № 450 від 07.08 .02 р.// Інформаційний збірник Міністерства освіти і науки України. - 2002. - № 22. - С. 3-11.

\section{REFERENCES (TRANSLATED \& TRANSLITERATED)}

1. Mishchenko S. G. Naukovo-metodychna robota yak pidgruntia rozvytku profesiinoi kompetentnosti vykladacha koledzhu [Scientific and Methodological Work as the Basis for the College Teacher's Professional Competence Development] / S. G. Mishhenko// Pedagogika formuvannia tvorchoi osobystosti u vyshchii i zahal'noosvitnii shkolakh [Pedagogy of the Creative Person's Formation in Higher and Secondary Schools] : zb. nauk. pr.] / [Redkol. : T. I. Sushchenko (holov . red . ) ta in. ]. - Zaporizhzhia : KPU, 2016. - Vyp. 51 (104). - S. 239-245.

2. Farafonova A. K. Tsyklova komisiia, yak vazhlyva lanka systemy upravlinnia navchal'no-metodychnoiu robotoiu [The Cyclical Commission as an Important Link in the Management of Teaching and Methodological Work] / A. K. Farafonova // Suchasni problemy i shliakhy vdoskonalennia upravlinnia vyshchymy navchalnymy zakladamy I-II rivniv akredytatsii [Modern Problems and Ways to Improve Management of Higher Educational Institutions of the 1st and 2nd Levels of Accreditation] : [zbirnyk materialiv naukovo-praktychnoi konferentsii pedahohichnykh pratsivnykiv vyshchykh navchalnykh zakladiv I-II rivniv akredytatsii Kharkivskoi oblasti (24 liutoho 2006 r.)]. - Kharkiv, 2013. - S. 225-226.

3. Pro zatverdzhennia norm chasu dlia planuvannia i obliku navchal'noi roboty ta perelikiv osnovnykh vydiv metodychnoi, naukovoi y orhanizatsiinoi roboty pedahohichnykh i naukovo-pedahohichnych pratsivnykiv vyshchych navchalnych zakladiv [On Approval of Time Standards for the Planning and Accounting of Educational Work and Lists of Major Types of Methodological, Scientific and Organizational Work of Pedagogical and Scientific Staff of Higher Educational Institutions] : nakaz MON Ukrainy № 450 vid 07.08.02 r. // Informatsiinyi zbirnyk Ministerstva osvity i nauky Ukrainy [Information Collection of the Ministry of Education and Science of Ukraine]. -2002 - № 22. - S. 3-11.

\section{Козаченко Г. В. Цикловая методическая комиссия как середа развития педагогической компетентности преподавателей фармацевтического профиля.}

В статье рассматривается роль ичикловой методической комиссии фармацевтических дисичиплин 8 развитии педагогической компетентности преподавателей фармацевтического профиля, определено содержание работы иүикловой методической комиссии, структуру педагогической компетентности, определено роль преподавателя фармацевтического профиля в образовательном процессе высшего учебного заведения. Акиентировано, что именно иикловая методическая комиссия образовывает

систему научно-методической работы, направленной на обеспечение развивательного еффекта образовательного прочесса, способствует развитию у преподавателей фармацевтического профиля педагогической компетентности.

Ключевые слова: цикловая методическая комиссия фармацевтических дисциплин, преподаватели фармацевтического профиля, развитие педагогической компетентности. 


\section{Kozachenko G. V. Cyclic Methodical Commission as an Environment for the Development of Pedagogical Competence of Pharmaceutical Profile Teachers.}

The article considers the role of the cyclic methodical commission of pharmaceutical disciplines in the development of the pedagogical competence of the pharmaceutical profile teachers. It has been also determined the content of the cyclic methodical commission, the structure of pedagogical competence, and the role of pharmaceutical profile teacher in the educational process of the institution of higher education. It is emphasized that the cyclic commission creates a system of scientific and methodical work that is aimed at providing the developmental effect of the educational process, and promotes the development of pedagogical competence among the pharmaceutical profile teachers.

The problem of teachers' pedagogical competence development within the pharmaceutical institutions of higher education gains ground in the context of the renewal of the educational field, which, is integrated into the international community, and puts forward the demands on the teacher of higher education, his personality and professional activities. At the same time, among the teachers of pharmaceutical institution of higher education raises a problem of their pedagogical competence development and formation. These teachers are guided by the implementation of the pharmaceutical and educational fields' synergy, and therefore should integrate the qualities that are common to the successful implementation of one and another type of activity. The dynamism of the college teacher's pedagogical competence, that manifests itself in its development, depends on the effectiveness of the organization of scientific and methodological work of the college, in particular on the coherent and meaningful work of the cyclic methodical commission of pharmaceutical disciplines.

The analysis of the directions and content of the cyclic methodical commission of pharmaceutical disciplines revealed the existence of the important principles for its effective functioning. These principles are: the selection of rational forms; the freedom of teachers ' creativity, their right to innovation activity; enforcement of teachers' rights to have a free choice of forms, methods and means of teaching, determining the effectiveness of their pedagogical activities depending on the level of students' knowledge quality; avoiding formal reporting and other documents.

Key words: cyclic methodical commission of pharmaceutical disciplines, pharmaceutical profile teachers, development of pedagogical competence. 